\title{
PERCEIVED LUXURY VALUE DAN PENGARUHNYA TERHADAP MINAT MENGINAP DI HOTEL BINTANG LIMA
}

\author{
Nevia Putri Hariwijaya ${ }^{1}$, Vincentia Celia Hodianto ${ }^{2}$, Sienny Thio $^{3 *}$ \\ ${ }^{1,2,3}$ Program Studi Manajemen Perhotelan, Fakultas Bisnis dan Ekonomi, Universitas Kristen Petra \\ Jl. Siwalankerto 121-131, Surabaya, 60236, Indonesia \\ Email: ${ }^{1}$ nevia724@gmail.com; ${ }^{2}$ vincentiacelia@gmail.com; ${ }^{3}$ sienny@ petra.ac.id
}

*Penulis korespondensi

\begin{abstract}
Abstrak: Penelitian ini bertujuan untuk menganalisa perceived luxury value yang dilihat dari dari nilai utilitarian, hedonis, finansial, relasional dan simbolik dan pengaruhnya terhadap minat menginap di hotel bintang lima. Penelitian ini menggunakan pendekatan kuantitatif kausal dengan pengambilan sampel menggunakan purposive sampling. Kuesioner disebarkan kepada 104 responden yang pernah menginap di hotel bintang lima dalam dua tahun terakhir. Analisa statistik deskriptif dan regresi linier berganda digunakan untuk menganalisa data. Hasil pengolahan data menunjukkan bahwa nilai hedonis merupakan nilai luxury yang dipersepsikan paling tinggi diikuti oleh nilai utilitarian dan nilai finansial. Perceived luxury values yang dilihat dari nilai hedonis dan finansial mempunyai pengaruh yang positif dan signifikan terhadap minat menginap di hotel bintang lima.
\end{abstract}

Kata kunci: Perceived luxury value; nilai utilitarian; nilai hedonis; nilai simbolik; nilai finansial; nilai relasional; minat menginap.

Abstract: The purpose of this paper is to analyze perceived luxury value, which are utilitarian value, hedonic value, financial value, relational value and symbolic value, and its impact on intention to stay at five-star hotels. This paper employed a quantitative causal approach using purposive sampling method. Questionnaires were distributed to 104 respondents who have ever stayed at five-star hotels in the last two years. Descriptive statistic and multiple regression analysis were utilized to analyze the data. The results indicated that hedonic value was perceived the highest, followed by utilitarian and financial value. Perceived luxury value of hedonic and financial value had positive and significant effects on their intention to stay at five-star hotels.

Keywords: Perceived luxury value; utilitarian value; hedonic value; symbolic value; financial value; relational value; visit intention.

\section{PENDAHULUAN}

Industri perhotelan yang luxury sedang mengalami pertumbuhan yang cepat dalam dekade terakhir (Yang \& Mattila, 2016). Jumlah hotel luxury secara global bertumbuh $19 \%$ dari dekade sebelumnya dan pertumbuhan ini disertai dengan peningkatan permintaan sebanyak 105 juta kamar per tahun dari dekade sebelumnya (Freitag, 2019). Luxury diartikan sebagai kehidupan yang mudah, penuh kemewahan dan kesenangan (Tynan et al., 2010). Dalam konteks penelitian ini luxury diartikan sebagai gaya hidup mewah oleh konsumen yang ditunjukkan dengan kecenderungan mengkonsumsi produk atau jasa dengan harga yang mahal. Hotel bintang lima mencakup komponen dari "luxury", seperti harga yang mahal, fasilitas lengkap dan mewah, pelayanan yang penuh perhatian serta fisik hotel yang indah, dimana hal ini sama dengan definisi hotel bintang lima menurut Forbes Travel Guide (dalam Barrows, Powers, \& Reynolds, 2011). Oleh karena itu, perceived luxury value dapat digunakan untuk menganalisa nilai dari konsumen hotel bintang lima.

Hotel bintang lima di Indonesia terus mengalami pertumbuhan dari tahun ke tahun dengan peningkatan jumlah kamar sebanyak kurang lebih 9000 kamar dalam dekade terakhir ini (Salanto, 2018). Industri perhotelan dunia sekarang sedang terpukul oleh adanya pandemi global yang tidak terduga. Akan tetapi, diprediksi bahwa industri ini akan kembali bangkit seusai pandemi global berakhir, yang dapat dilihat dari peningkatan tingkat okupansi hotel dan villa di Bali yang mulai meningkat mencapai $70 \%$ dan peningkatan mencapai 50\% di hotel Jawa Timur (Suarna, 2020; "Industri Hotel Mulai Menggeliat", September 7, 2020).

Hotel premium saat ini sedang menghadapi tantangan untuk menumbuhkan dan mempertahankan daya saing untuk menarik minat konsumen (Yang \& Mattila, 2016). Menurut Armstrong et al. (2015), masyarakat di seluruh dunia semakin mencari nilai yang lebih besar ketika melakukan pembelian sehingga merek-merek luxury ternama juga semakin mementingkan adanya nilai yang besar dari produk yang ditawarkan. Peng dan Chen (2019) mengatakan bahwa organisasi yang berfokus kepada customer perceived value akan memiliki keunggulan bersaing yang berkelanjutan. Perceived luxury value sendiri merupakan adaptasi dari customer perceived value yang mempelajari perilaku konsumsi dari produk dan 
jasa luxury. Perceived luxury value adalah persepsi nilai dari konsumen yang disesuaikan dengan komponen produk dan jasa "luxury", seperti kualitas, hedonisme, keunikan, dan status, sebagai kompensasi atas harganya yang tinggi (Kang, 2017). Pengunjung cenderung lebih tertarik untuk membeli, menggunakan, dan merasakan barang atau jasa jika persepsinya terhadap barang atau jasa tersebut lebih tinggi (Amin \& Tarun, 2019).

Telah banyak penelitian yang dilakukan mengenai perceived luxury value. Meskipun demikian, penelitian mengenai industri perhotelan luxury masih belum banyak dilakukan jika dibandingkan pada produk luxury (Yang \& Mattila, 2016). Dalam konteks hotel luxury, penelitian terdahulu membagi dimensi dari nilai luxury dari beberapa dimensi yang berbeda seperti yang terlihat pada Tabel 1.

Tabel 1. Dimensi Luxury Value dari Penelitian Terdahulu pada hotel luxury

\begin{tabular}{ll}
\hline \multicolumn{1}{c}{ Peneliti } & \multicolumn{1}{c}{ Dimensi Luxury Value } \\
\hline Peng \& Chen, (2019) & Fungsional, Finansial, \\
& Hedonis, Simbolik \\
Wu \& Yang, (2018) & Fungsional, Simbolik, \\
& Hedonis, Relasional, \\
& Finansial \\
Alan, et al. (2016) & Fungsional, Sosial, \\
& Individual, Finansial \\
Chen \& Peng, (2014) & Fungsional, Simbolik, \\
& Experiential \\
Raza,et al. (2012) & Fungsional, Simbolik \\
\hline
\end{tabular}

Wu dan Yang (2018) melihat nilai luxury dari lima aspek yaitu fungsional, hedonis, simbolik, relasional, dan finansial dimana nilai-nilai luxury tersebut sudah mencakup semua dimensi yang telah dipaparkan oleh penelitian terdahulu (Peng \& Chen, 2019; Alan et al, 2016; Chen \& Peng, 2014, Raza et al, 2012) khususnya yang menggunakan hotel luxury sebagai objek penelitiannya. Oleh karena itu, pada penelitian ini penulis mengadopsi lima dimensi perceived luxury value dari penelitian Wu dan Yang (2018), yaitu nilai fungsional, hedonis, simbolik, relasional dan finansial.

Penelitian mengenai perceived luxury value di industri perhotelan di Indonesia masih belum banyak ditemukan sehingga belum diketahui secara jelas bagaimana persepsi nilai dari masyarakat Indonesia dalam menikmati konsumsi luxury khususnya ketika menginap di hotel bintang lima. Berdasarkan permasalahan dan penelitian terdahulu, maka penulis ingin mengetahui lebih dalam persepsi masyarakat Indonesia terhadap luxury value khususnya ketika menginap di hotel bintang lima serta pengaruhnya terhadap minat untuk menginap.

\section{LANDASAN TEORI}

\section{Customer Value}

Customer value adalah persepsi pelanggan dalam mengevaluasi atribut produk, kinerja, dan konsekuensi yang timbul dari penggunaan yang memfasilitasi atau menghalau pencapaian tujuan pelanggan (Woodruff, 1997). Sedangkan, menurut Fernández dan Bonillo (2008), customer value merupakan hasil proses konsumen mengklasifikasikan dan mengingat suatu produk atau jasa. Customer value penting bagi suatu organisasi saat melakukan peningkatan kualitas untuk menyesuaikan keinginan dan kebutuhan konsumen.

Customer value dapat dibagi menjadi 2 kategori yaitu desired customer value dan perceived customer value (Raza et al., 2012). Desired customer value adalah nilai yang dicari konsumen untuk mencapai tujuan atau keinginannya (Flint, Woodruff, \& Gardial, 1997). Perceived customer value lebih berfokus pada penilaian akan manfaat dan pengorbanan, sementara desired customer value berfokus pada kebutuhan dan keinginan pelanggan yang sifatnya lebih abstrak daripada perceived customer value (Graf \& Maas, 2008). Perceived customer value bervariasi dalam konteks yang berbeda. Salah satunya dalam konteks luxury yaitu perceived luxury value.

\section{Perceived Luxury Value}

Perceived luxury value merupakan variasi dari customer perceived value yang mempelajari perilaku konsumsi dari produk dan jasa luxury (Peng \& Chen, 2019). Hal ini dilakukan dengan memasukkan komponen produk dan jasa luxury, seperti kualitas, hedonisme, keunikan, dan status, sebagai kompensasi atas harganya yang tinggi (Kang, 2017). Hal ini sejalan dengan pendapat Tynan et al. (2010) bahwa karena jika dibandingkan dengan non-luxury, produk dan jasa luxury cenderung memiliki kualitas premium, gaya kekinian, nilai hedonis tinggi, dan harga yang jauh lebih mahal. Perceived luxury value dapat diartikan juga sebagai nilai yang ingin didapatkan konsumen ketika melakukan konsumsi luxury (Wu \& Yang, 2018).

Perceived luxury value merupakan sesuatu yang perlu dipahami karena merupakan alasan konsumen mengkonsumsi produk atau jasa luxury yang kemudian dapat mendorong minat belinya (Amelia \& Hidayatullah, 2020). Perceived luxury value sangat penting dalam memilih akomodasi karena mengandung komponen "memberi" dan "menerima" antara perusahaan dengan pengunjung (Yang \& Lau, 2015). Dari penelitian-penelitian tersebut dapat dikatakan bahwa organisasi yang berfokus kepada perceived 
luxury value akan memiliki keunggulan bersaing yang berkelanjutan. Wu dan Yang (2018) mengklasifikasikan 5 dimensi perceived luxury value mencakup secara komprehensif semua dimensi dari penelitianpenelitian terdahulu, yaitu nilai utilitarian, simbolik, hedonis, relasional dan Finansial.

\section{Nilai Utilitarian}

Nilai ini juga sering disebut nilai fungsional. Nilai utilitarian berkaitan dengan sejauh mana produk atau jasa luxury memiliki karakteristik atau fungsi yang diinginkan konsumen (Shukla \& Purani, 2012). Menurut pandangan konsumen luxury, pembelian produk dan jasa luxury tidak hanya untuk menunjukkan status, tetapi juga untuk mendapatkan kualitas dan performa yang lebih tinggi dari merek yang unggul, sehingga meningkatkan kesediaan konsumen untuk membayar lebih (Alan et al., 2016; Wu \& Yang, 2018).

Nilai utilitarian berbeda untuk produk dan jasa luxury. Dalam konteks produk luxury, kualitas dapat terlihat melalui bahan, desain, teknologi, dan keindahan. Sedangkan, pada industri jasa penekanan terjadi pada elemen yang tidak berwujud seperti kualitas layanan dan atmosfer (Yang \& Mattila, 2016). Nilai utilitarian menekankan pada kualitas dan fungsi dari produk atau jasa luxury. Dalam konteks hotel luxury sendiri, Wu dan Yang (2018) mengatakan bahwa lingkungan fisik, seperti suasana dan fasilitas hotel, serta interaksi antar manusia, seperti keramahan dan profesionalisme staf hotel, merupakan komponen penting dalam pengalaman menginap konsumen di hotel luxury.

\section{Nilai Simbolik}

Nilai simbolik berkaitan dengan sejauh mana konsumen mengaitkan psikologis terhadap suatu produk atau jasa (Shukla \& Purani, 2012). Produk atau jasa luxury menyebabkan konsumen merasa lebih baik dan nyaman akan dirinya sendiri karena memberikan status sosial dan sebagai simbol kekayaan (Shukla \& Purani, 2012; Peng \& Chen, 2019). Konsumsi luxury dianggap merupakan cara yang efektif untuk menaiki tangga sosial di masyarakat (Wu \& Yang, 2018).

Dengan tampilan yang mencolok, konsumen akan dapat menunjukkan secara tidak langsung kekuasaan, kekayaan, citra sosial, dan prestisenya yang tinggi di antara lingkungan sosialnya. Hal ini juga senada dengan pendapat Wu dan Yang (2018) bahwa konsumen produk atau jasa luxury biasanya akan lebih puas dengan nilai simbolik daripada nilai fungsionalnya. Meskipun nilai simbolik digunakan dalam konsumsi luxury, penelitian sebelumnya menemukan bahwa konsumen lebih memilih untuk menggunakan produk yang jelas berwujud karena lebih terlihat mencolok dibandingkan dengan produk yang tidak berwujud, seperti dalam industri jasa (Yang \& Mattila, 2016; Wu \& Yang, 2018).

\section{Nilai Hedonis}

Nilai hedonis mengarah pada keuntungan yang didapat secara emosional, serta sejauh mana produk dapat menciptakan pengalaman yang menyenangkan bagi konsumen (Yang \& Mattila, 2016). Konsumsi luxury biasanya merupakan konsumsi untuk hedonisme dan emosi konsumen (Wu \& Yang, 2018). Hal ini senada dengan pendapat Peng dan Chen (2019) bahwa banyak konsumen yang membeli produk atau jasa luxury karena perasaan memanjakan diri yang dibawa oleh konsumsi tersebut.

Dalam industri hotel yang merupakan industri dimana konsumen membeli pengalaman, konsumen cenderung mencari kepuasan emosi dan rasa senang (Wu \& Yang, 2018). Oleh karena itu, banyak perusahaan di industri ini yang berfokus pada menciptakan perasaan tersebut saat berkunjung (Yang \& Mattila, 2016; Chen \& Peng, 2018). Selain itu penelitian sebelumnya juga menemukan bahwa untuk konsumsi budget, fungsi atau utilitarian adalah yang utama, sementara kepuasan dan kesenangan adalah yang utama untuk konsumsi luxury (Wu \& Yang, 2018).

\section{Nilai Relasional}

Nilai relasional berasal dari perspektif value cocreation yang pertama kali dimasukkan ke dimensi perceived luxury value oleh Tynan et al. (2010). Value co-creation memiliki makna bahwa konsumen dan perusahaan sama-sama memiliki peran yang aktif dalam proses pembelian (Wu \& Yang, 2018). Lebih lanjut Wu dan Yang (2018) menekankan pentingnya value co-creation dalam industri perhotelan karena konsumen ada di tempat terjadinya pembelian sehingga sangat memungkinkan terjadinya interaksi yang kemudian akan membentuk nilai. Dengan kata lain, nilai hanya terbentuk ketika kedua pihak, pembeli dan penjual, berinteraksi sehingga tidak ada pembatas antara produksi dan konsumsi (Tynan et al., 2010).

Nilai relasional berkaitan dengan kemampuan konsumen untuk terlibat secara aktif dalam konsumsi dengan belajar sejarah merek, membentuk komunitas untuk suatu merek, ataupun membangun hubungan antara konsumen dengan merek (Wu \& Yang, 2018). Penelitian Tynan et al. (2010) mengemukakan banyak konsumen di Barat yang menganggap merek hotel luxury favorit sebagai bagian dari gaya hidupnya 
sehingga konsumen membangun hubungan dan cenderung merayakan acara-acara penting dan momen spesial di hotel tersebut.

\section{Nilai Finansial}

Nilai finansial berkaitan dengan perbandingan antara biaya yang dibayarkan dengan manfaat yang didapat konsumen saat melakukan pembelian luxury (Wu \& Yang, 2018). Menurut Tynan et al. (2010) nilai finansial didasari aspek eksklusivitas, efek perfeksionisme, dan kelangkaan. Dapat dilihat bahwa produk dan jasa luxury identik dengan kelangkaan karena hanya demografi masyarakat tertentu yang dapat mengkonsumsinya. Shukla dan Purani (2012) berpendapat bahwa harga yang tinggi identik dengan kualitas dan keunikan yang tinggi yang merupakan hal yang dicari oleh konsumen luxury. Akan tetapi meskipun konsumen luxury bersedia membayar lebih, manfaat dan pengalaman yang seimbang tetap diutamakan dan menjadi atribut yang penting dalam industri perhotelan luxury (Yang \& Mattila, 2016; Wu \& Yang, 2018). Nilai finansial pada industri perhotelan luxury menekankan pada harga yang wajar dan pengeluaran yang sepadan dengan yang didapatkan (Yang \& Mattila, 2016).

\section{Minat Menginap}

Menurut Liu (2017), minat merupakan aktivitas psikis yang timbul karena adanya perasaan atau afektif dan pikiran atau kognitif terhadap suatu barang atau jasa yang diinginkan (dalam Junaidi, 2015). Minat pembelian adalah bagian dari perilaku konsumen yang menentukan sikap saat mengkonsumsi dan kecenderungan perilaku sebelum memutuskan untuk membeli (Yulisetiarini, et al., 2017). Dapat dilihat bahwa minat beli merupakan evaluasi subjektif dan berbedabeda untuk tiap konsumen.

Dalam penjelasan selanjutnya penulis akan menggunakan terminologi minat menginap dalam konteks penelitian ini. Minat menginap sendiri dapat diartikan sebagai kemauan individu untuk menginap atau datang ke suatu lokasi yang telah disediakan oleh pengelola (Yacob et al., 2019). Minat menginap sangat dipengaruhi oleh kualitas layanan yang kemudian akan membentuk citra merek (Liu et al., 2017). Menurut Sari dan Kusuma (2014), minat menginap merupakan faktor yang sangat penting karena dapat mengukur kemungkinan konsumen membeli suatu produk, dan semakin tinggi minat tersebut, maka semakin tinggi pula kesediaan konsumen untuk membeli produk atau jasa. Minat menginap adalah prediktor penting perilaku pembelian aktual sehingga dapat dikatakan bahwa dengan minat menginap, pemasar dapat memprediksi perilaku konsumen di masa mendatang (Lien, et al., 2015).

\section{Kerangka Konseptual}

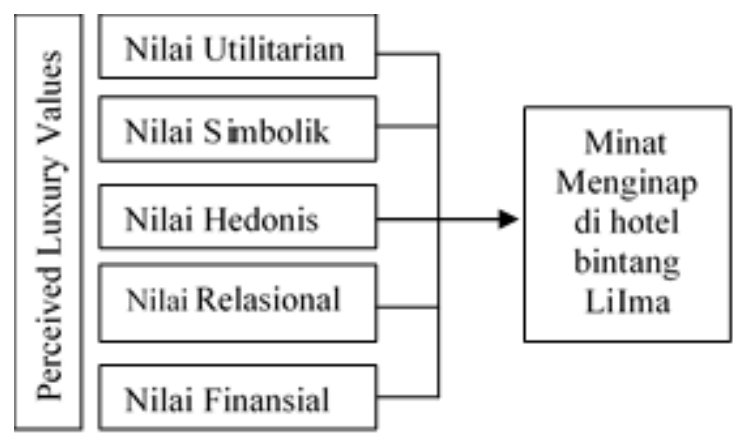

Gambar 1. Kerangka Konseptual

\section{Hubungan antara Perceived Luxury Values dan Minat Menginap}

Penelitian yang dilakukan Yang dan Mattila (2016) menyatakan bahwa nilai utilitarian berpengaruh signifikan dan positif terhadap minat konsumen untuk mengunjungi restoran luxury. Hal ini senada dengan penelitian yang dilakukan oleh Amelia dan Hidayatullah (2020), dimana nilai utilitarian berpengaruh positif pada minat beli di restoran luxury di Indonesia. Dalam konteks hotel luxury, Wu dan Yang (2018) juga menyimpulkan bahwa nilai utilitarian berpengaruh positif terhadap minat konsumen untuk menginap. Pengaruh ini dapat disebabkan oleh persepsi konsumen atas fasilitas hotel, baik yang terlihat maupun tidak terlihat, seperti desain dan dekorasi, maupun atmosfer hotel. Jika komponen-komponen ini sesuai dengan selera konsumen, maka persepsi mereka akan hotel tersebut akan semakin positif dan dapat menimbulkan minat untuk menginap, begitu juga sebaliknya. $\mathrm{H}_{1}$ : Nilai utilitarian berpengaruh signifikan terhadap minat masyarakat Indonesia untuk menginap di hotel bintang lima.

Dalam konteks jasa luxury yaitu pada industri perhotelan, Yang dan Matilla (2016) mengemukakan bahwa nilai simbolik tidak berpengaruh signifikan pada konsumsi restoran luxury di Amerika Serikat. Penelitian yang dilakukan oleh Wu dan Yang (2018) juga menyatakan bahwa nilai simbolik tidak berpengaruh signifikan pada tamu Cina yang menginap di hotel luxury. Pengaruh ini dapat disebabkan oleh sifat jasa hotel yang berjenis tidak terlihat, dimana jika tidak terlihat, maka akan sulit menjadi sarana konsumen untuk menunjukkan kekuasaan, status, dan kelas sosial yang tinggi. Jika dibandingkan dengan produk luxury 
seperti tas, baju, dan lain-lain yang bersifat jelas terlihat, akan lebih mudah bagi konsumen untuk menunjukkan status, kekuasaan, dan lain-lain tersebut, sehingga konsumen cenderung lebih menggunakan produk luxury untuk menunjukkan nilai simboliknya.

$\mathrm{H}_{2}$ : Nilai simbolik tidak berpengaruh signifikan terhadap minat masyarakat Indonesia untuk menginap di hotel bintang lima.

Pada penelitian Chen dan Peng (2014) disimpulkan bahwa nilai hedonis berpengaruh langsung terhadap sikap konsumen Cina dan Taiwan saat menginap di hotel luxury maupun saat berkunjung ke restoran luxury saat berlibur. Peng dan Chen (2019) juga mengatakan bahwa nilai hedonis berpengaruh signifikan terhadap emosi masyarakat Taiwan yang juga akan berpengaruh signifikan terhadap minat menginap kembali di hotel luxury. Sedangkan menurut Yang dan Mattila (2016) pada restoran luxury di Amerika Serikat, nilai hedonis merupakan nilai yang paling berpengaruh. Begitu pula dengan penelitian $\mathrm{Wu}$ dan Yang (2018) bahwa nilai hedonis adalah nilai yang paling dominan pada minat beli masyarakat Cina di hotel luxury. Hal ini disebabkan hedonis merupakan bagian yang sangat penting dalam konsumsi luxury.

$\mathrm{H}_{3}$ : Nilai hedonis berpengaruh signifikan terhadap minat masyarakat Indonesia untuk menginap di hotel bintang lima

Dalam konteks jasa luxury pada industri perhotelan di Cina, Wu dan Yang (2018) mengatakan nilai relasional tidak berpengaruh signifikan terhadap minat menginap pada hotel luxury. Hal tersebut dikarenakan hotel luxury merupakan suatu hal yang baru bagi Sebagian besar masyarakat Cina yang lebih berfokus pada manfaat yang berwujud dibandingkan dengan hubungan dengan merek yang bersifat tidak berwujud. Begitu pula keadaan pasar luxury di Indonesia yang tergolong cukup baru karena baru berkembang pada satu dekade terakhir ini dan juga masyarakat Indonesia semakin mementingkan merek terkenal, tetapi kurang mementingkan hubungan dengan merek karena konsumen Indonesia menjadi lebih sadar akan harga dalam melakukan pembelian ("The luxury market", n.d.).

$\mathrm{H}_{4}$ : Nilai relasional tidak berpengaruh signifikan terhadap minat masyarakat Indonesia untuk menginap di hotel bintang lima.

Yang dan Mattila (2016) dalam penelitiannya menyatakan bahwa nilai finansial berpengaruh signifikan pada minat beli di restoran luxury di Amerika Serikat. Penelitian yang dilakukan oleh Wu dan Yang (2018) juga menyimpulkan hal yang sama bahwa nilai finansial berpengaruh positif terhadap minat beli masyarakat Cina pada hotel luxury. Hal ini dapat disebabkan oleh sifat hotel yang merupakan akomodasi sementara, dimana konsumsinya hanya bertahan selama konsumen menginap, sehingga konsumen cenderung lebih sensitif akan pengalaman dan manfaat yang didapatkan selama melakukan konsumsi atau menginap di hotel (Peng \& Chen, 2018). Jika persepsi finansial konsumen akan suatu hotel baik, maka akan meningkatkan minat konsumen untuk menginap. Konsumen yang cenderung menginginkan manfaat yang lebih banyak untuk kompensasi harga hotel yang tinggi. Manfaat ini dapat berupa pelayanan yang lebih baik maupun aktivitas-aktivitas unik yang dapat meningkatkan persepsi finansial tamu akan hotel dan kemudian dapat menimbulkan minat untuk menginap. $\mathrm{H}_{5}$ : Nilai finansial berpengaruh signifikan terhadap minat masyarakat Indonesia untuk menginap di hotel bintang lima.

\section{METODE PENELITIAN}

Penelitian ini merupakan penelitian kuantitatif kausal dimana penulis menganalisis hubungan sebabakibat antara nilai-nilai luxury yang dilihat dari lima varibel yaitu nilai nilai utilitarian, simbolik, hedonis, relasional dan finansial terhadap minat untuk menginap di hotel bintang lima. Teknik non-probability sampling dengan metode purposive sampling digunakan dengan kriteria sampelnya dalah masyarakat Indonesia yang berusia minimal 17 tahun dan pernah menginap di hotel bintang lima dalam jangka waktu 2 tahun terakhir (Oktober 2018-September 2020). Penyebaran kuesioner dilakukan secara online menggunakan Google Form, melalui media sosial LINE Messenger, Instagram, dan Whatsapp. Dari 167 kuesioner yang diperoleh, sebanyak 63 sampel tidak memenuhi kriteria sehingga hanya 104 kuesioner yang dapat digunakan untuk analisa lebih lanjut.

Setelah data terkumpul, penulis mengolah data dengan bantuan Statistical Package for Social Sciences (SPSS16). Dari hasil uji validitas, diketahui semua nilai korelasi memiliki signifikansi $<0,05$ dan Cronbach's Alpha berkisar antara 0,609-0,875 atau > 0,6 sehingga dapat disimpulkan semua indikator dan varibel dinyatakan valid dan reliabel. Selanjutnya, uji asumsi klasik dilakukan sebagai persyaratan yang harus dipenuhi untuk melakukan analisa regresi linier. Hasil uji Kolmogorov-Smirnov menunjukkan nilai 0,149 dimana angka ini lebih besar dari 0,05 yang berarti bahwa data berdistribusi normal. Dari uji multikolinearitas, diketahui nilai tolerance untuk semua nilai luxury adalah diatas 0,10 dan nilai VIF kurang dari 10, sehingga dapat disimpulkan tidak terdapat 
multikolinearitas. Sedangkan untuk uji heteroskedastisitas, dari hasil scatterplot tidak terlihat titik-titik yang membentuk pola yang jelas dan menyebar diatas dan dibawah angka 0 pada sumbu $\mathrm{Y}$ yang berarti tidak terjadi heteroskedastisitas.

Setelah dinyatakan valid dan reliabel, serta uji asumsi klasik telah terpenuhi, maka pengujian kausal dengan menggunakan regresi linier berganda dan koefisien deteminasi berganda dapat dilakukan. Pembuktikan hipotesis, dilakukan dengan menggunakan Uji F dan Uji T. Analisa statistik deskripsi juga dilakukan dengan menghitung nilai mean dan standar deviasi dari masing-masing indikator untuk memberikan gambaran mengenai persepsi konsumen terhadap nilai luxury ketika menginap di hotel bintang lima.

\section{HASIL DAN PEMBAHASAN}

\section{Karakterisitk Responden}

Dari Tabel 2 dibawah dapat dilihat bahwa responden perempuan sebesar $62.5 \%$ dengan mayoritas berusia antara 17-22 tahun dan berstatus sebagai pelajar/mahasiswa. Uang saku responden rara-rata perbulan di bawah Rp.5.000.000,- dan mayoritas responden menginap di hotel bintang lima 1-3 kali (90\%) dalam kurun waktu 2 tahun terakhir dengan tujuan untuk berlibur.

Tabel 2. Karakterisitk Responden

\begin{tabular}{lcc}
\hline \multicolumn{1}{c}{ Variabel } & $\mathbf{N}$ & $\mathbf{\%}$ \\
\hline Jenis Kelamin & & \\
Laki-laki & 39 & 37.5 \\
Perempuan & 65 & 62.5 \\
\hline Usia & & \\
17-22 tahun & 46 & 44.2 \\
23-30 tahun & 13 & 12.5 \\
31- 45 tahun & 23 & 22.1 \\
46 -60 tahun & 21 & 20.2 \\
>60 tahun & 1 & 1.0 \\
\hline Pekerjaan & & \\
Pelajar/Mahasiswa & 47 & 45.2 \\
Pegawai Swasta & 24 & 23.1 \\
Profesional (dokter, guru,dll) & 4 & 3.8 \\
Wiraswasta/Entrepeneur & 19 & 18.3 \\
Lain-lain & 1 & 1.0 \\
\hline Pendidikan & & \\
SMA/SMK/sederajat & 23 & 22.1 \\
Diploma/sederajat & 8 & 7.7 \\
S1/sederajat & 66 & 63.5 \\
S2/S3 & 7 & 6.7 \\
\hline Uang Saku/Penghasilan per bulan & & \\
< Rp. 5.000.000 & 47 & 45.2 \\
Rp.5.000.000 - 15.000.000 & 29 & 27.9 \\
Rp.15.000.001 -.30.000.000 & 19 & 18.3 \\
Rp.30.000.000 - 50.000.000 & 3 & 2.9 \\
> Rp. 50.000.000 & 6 & 5.8 \\
\hline
\end{tabular}

\begin{tabular}{lcc}
\hline Frekuensi menginap di hotel bintang & & \\
lima (Oct'18-Sep'20): & & \\
1-3 kali & 90 & 86.5 \\
4-7 kali & 10 & 9.6 \\
>10 kali & 4 & 3.8 \\
\hline Tujuan travelling: & & \\
Liburan & 96 & 75.0 \\
Bisnis/pekerjaan & 11 & 8.6 \\
Mengunjungi keluarga/relasi & 13 & 10.2 \\
Kesehatan & 5 & 3.9 \\
Lain-lain & 1 & 0.8 \\
\hline
\end{tabular}

\section{Analisa Statistik Deskriptif}

Analisa mean dan standar deviasi dalam penelitian ini digunakan untuk mengetahui persepsi reponden terhadap nilai luxury ketika menginap di hotel bintang lima. Pesepsi responden ini diukur dengan menggunakan skala likert dari 1 (tidak setuju) sampai 5 (sangat setuju). Hasil mean dari kelima dimensi perceived luxury value dapat dilihat pada tabel 3 di bawah ini.

Tabel 3. Hasil Mean dan Standar Deviasi

\begin{tabular}{|c|c|c|}
\hline Pernyataan & Mean & SD \\
\hline $\begin{array}{l}\text { 1. Amenities yang berkualitas (sabun, } \\
\text { shampoo, sikat gigi, dll) mendorong } \\
\text { untuk menginap di hotel bintang } \\
\text { lima }\end{array}$ & 3,61 & 1,083 \\
\hline $\begin{array}{l}\text { 2. Layanan yang penuh perhatian } \\
\text { mendorong untuk menginap di hotel } \\
\text { bintang lima }\end{array}$ & 4,63 & 0,576 \\
\hline $\begin{array}{l}\text { 3. Hotel bintang lima yang terpercaya } \\
\text { mendorong untuk menginap }\end{array}$ & 4,69 & 0,559 \\
\hline $\begin{array}{l}\text { 4. Layanan dan produk yang personal } \\
\text { mendorong untuk menginap di hotel } \\
\text { bintang lima }\end{array}$ & 4,49 & 0,697 \\
\hline Nilai Utilitarian & 4,36 & 0,534 \\
\hline $\begin{array}{l}\text { 1. Menginap di hotel bintang lima } \\
\text { adalah simbol dari status }\end{array}$ & 3,06 & 1,213 \\
\hline $\begin{array}{l}\text { 2. Menginap di hotel bintang lima } \\
\text { adalah simbol dari } \\
\text { kekuasaan/wibawa }\end{array}$ & 2,88 & 1,212 \\
\hline $\begin{array}{l}\text { 3. Menginap di hotel bintang lima } \\
\text { dapat dikatakan sebagai sesuatu } \\
\text { yang penting }\end{array}$ & 3,03 & 1,153 \\
\hline $\begin{array}{l}\text { 4. Menginap di hotel bintang lima } \\
\text { supaya bisa sesuai dengan jaringan } \\
\text { sosial }\end{array}$ & 2,92 & 1,188 \\
\hline $\begin{array}{l}\text { 5. Menginap di hotel bintang lima } \\
\text { dapat meningkatkan citra sosial }\end{array}$ & 3,19 & 1,223 \\
\hline $\begin{array}{l}\text { 6. Menginap di hotel bintang lima } \\
\text { dapat membantu untuk lebih } \\
\text { dihargai oleh teman-teman }\end{array}$ & 2,74 & 1,207 \\
\hline
\end{tabular}




\begin{tabular}{|c|c|c|c|}
\hline \multicolumn{2}{|r|}{ Nilai Simbolik } & \multirow{2}{*}{$\begin{array}{r}\mathbf{2 , 9 7} \\
4,22\end{array}$} & \multirow{2}{*}{$\begin{array}{l}\mathbf{0 , 9 9 3} \\
0,847\end{array}$} \\
\hline 1. & $\begin{array}{l}\text { Cenderung menginap di hotel } \\
\text { bintang lima yang sesuai selera } \\
\text { keindahan }\end{array}$ & & \\
\hline 2. & $\begin{array}{l}\text { Menginap di hotel bintang lima } \\
\text { memberikan banyak kesenangan }\end{array}$ & 4,45 & 0,749 \\
\hline \multirow[t]{2}{*}{3.} & $\begin{array}{l}\text { Menginap di hotel bintang lima } \\
\text { merupakan cara untuk memanjakan } \\
\text { diri }\end{array}$ & 4,48 & 0,696 \\
\hline & Nilai Hedonis & 4,39 & 0,607 \\
\hline 1. & $\begin{array}{l}\text { Sering memilih hotel bintang lima } \\
\text { untuk merayakan momen spesial }\end{array}$ & 3,91 & 1,071 \\
\hline 2. & $\begin{array}{l}\text { Menginap di hotel bintang lima } \\
\text { adalah bagian penting dari gaya } \\
\text { hidup }\end{array}$ & 2,71 & 1,171 \\
\hline 3. & $\begin{array}{l}\text { Akan mempelajari sejarah hotel } \\
\text { bintang lima sebelum membuat } \\
\text { keputusan untuk menginap }\end{array}$ & 3,03 & 1,281 \\
\hline & Nilai Relasional & 3,22 & 0,884 \\
\hline 1. & $\begin{array}{l}\text { Membayar untuk menginap di hotel } \\
\text { bintang lima merupakan } \\
\text { pengeluaran yang pantas }\end{array}$ & 3,9 & 0,919 \\
\hline 2. & $\begin{array}{l}\text { Apa yang dibayar di hotel bintang } \\
\text { lima sesuai dengan apa yang } \\
\text { didapatkan }\end{array}$ & 4,31 & 0,725 \\
\hline 3. & $\begin{array}{l}\text { Membayar harga yang tinggi untuk } \\
\text { menginap di hotel bintang lima } \\
\text { merupakan sesuatu yang wajar }\end{array}$ & 3,88 & 1,03 \\
\hline & Nilai Finansial & 4,03 & 0,743 \\
\hline 1. & $\begin{array}{l}\text { Akan mempertimbangkan untuk } \\
\text { menginap di hotel bintang lima }\end{array}$ & 4,08 & 0,867 \\
\hline 2. & $\begin{array}{l}\text { Senang untuk menginap di hotel } \\
\text { bintang lima }\end{array}$ & 4,53 & 0,668 \\
\hline 3. & $\begin{array}{l}\text { Senang untuk merekomendasikan } \\
\text { hotel bintang lima ke orang lain }\end{array}$ & 4,06 & 0,993 \\
\hline & Minat Menginap & 4,22 & 0,629 \\
\hline
\end{tabular}

Dari tabel 3 diatas dapat dilihat bahwa menurut responden dari lima nilai perceived luxury value, nilai yang dipersepsikan paling tinggi adalah nilai hedonis dan utilitarian yang memiliki mean 4,39 dan 4,36 kemudian diikuti nilai finansial dan nilai relasional dengan nilai mean 4,03 dan 3,22. Sementara, nilai simbolik adalah nilai yang dipersepsikan paling rendah dengan nilai mean 2,97 .

Untuk nilai utilitarian, hotel bintang lima yang terpercaya (Mean=4,69) dan memberikan layanan yang penuh perhatian (Mean=4,63) menjadi indikator yang dipersepsikan paling tinggi oleh responden ketika menginap di hotel bintang lima. Sedangkan untuk nilai simbolik, menginap di hotel bintang lima dianggap mampu untuk meningkatkan citra sosialnya (Mean = $3,19)$. Dilihat dari nilai hedonisnya, menginap di hotel bintang lima dianggap merupakan cara untuk memanjakan diri $(M e a n=4,48)$ dan memberikan banyak kesenangan (Mean=4,45). Lebih lanjut, dapat dilihat bahwa untuk nilai relasional, hotel bintang lima cenderung dipersepsikan untuk merayakan momen spesial (Mean=3,91) dan untuk nilai finansial, responden melihat bahwa apa yang dibayarkan sesuai dengan apa yang didapatkan (Mean=4,31). Untuk minat menginap, indikator yang dipersepsikan plaing tinggi adalah rasa senang untuk menginap di hotel bintang lima $($ mean $=4,53)$

\section{Analisa Regresi Linear Berganda}

Analisa regresi linier berganda ini digunakan untuk mengetahui pengaruh dari perceived luxury values terhadap minat menginap di hotel bintang lima. Suatu variabel dikatakan signifikan apabila nilai signifikansinya $<0,05$. Berdasarkan hasil tabel 4 , dapat dilihat bahwa variabel yang memiliki pengaruh yang signifikan dalam minat menginap di hotel bintang lima adalah nilai hedonis dan nilai finansial karena nilai signifikansinya kurang dari 0,05 . Sementara, variabel yang tidak memiliki pengaruh yang signifikan dalam minat menginap di hotel bintang lima adalah nilai utilitarian, nilai simbolik dan nilai relasional. Hasil analisa regresi linear berganda dapat dilihat pada Table 4 dibawah ini:

Tabel 4. Hasil Analisa Regresi Linier Berganda

\begin{tabular}{lcccc}
\hline \multirow{2}{*}{\multicolumn{1}{c}{ Variabel }} & \multicolumn{2}{c}{$\begin{array}{c}\text { Unstandardized } \\
\text { Coefficients }\end{array}$} & t & Sig \\
\cline { 2 - 3 } & B & \multicolumn{1}{c}{ Std. Error } & & \\
\hline (Constant) & 3,754 & 1,432 & 2,621 & 0,10 \\
Nilai Utilitarian & 0,121 & 0,084 & 1,449 & 0,151 \\
Nilai Simbolik & $-0,001$ & 0,034 & $-0,027$ & 0,979 \\
Nilai Hedonis & 0,261 & 0,109 & 2,389 & 0,019 \\
Nilai Relasional & 0,004 & 0,082 & 0,050 & 0,960 \\
Nilai Finansial & 0,277 & 0,091 & 3,036 & 0,003 \\
\hline
\end{tabular}

Dari Tabel 4 dapat dibuat persamaan regresinya sebagai berikut:

$$
\begin{aligned}
\mathrm{Y}= & 3,754+0,121 \mathrm{X} 1-0,001 \mathrm{X} 2+0,261 \mathrm{X} 3+0,004 \\
& \mathrm{X} 4+0,277 \mathrm{X} 5
\end{aligned}
$$

Keterangan:

$\mathrm{X} 1=$ Nilai Utilitarian

$\mathrm{X} 2=$ Nilai Simbolik

X3 = Nilai Hedonis 
X4 = Nilai Relasional

$\mathrm{X} 5=$ Nilai Finansial

$\mathrm{Y}=$ Minat menginap

Nilai konstanta sebesar 3,754 mempunyai arti bahwa jika perceived luxury values yang diukur dari nilai utilitarian $(\mathrm{X} 1)$, nilai simbolik $(\mathrm{X} 2)$, nilai hedonis (X3), nilai relasional (X4), dan nilai finansial (X5) adalah nol atau konstan, maka minat menginap (Y) adalah sebesar 3,754. Hal ini berarti apabila perceived luxury values tidak memberikan pengaruh, maka minat menginap di hotel bintang lima masih tetap ada karena adanya faktor lain diluar luxury values.

Melihat arah pengaruhnya, nilai utilitarian, nilai hedonis, nilai relasional dan nilai finansial memiliki pengaruh yang positif terhadap minat menginap. Sementara, nilai simbolik memiliki pengaruh yang negatif, tetapi tidak memiliki signifikansi terhadap minat menginap.

\section{Koefisien Determinasi Berganda $\left(\mathbf{R}^{2}\right)$}

Koefisien determinasi berganda (R2) dilakukan untuk mengetahui seberapa besar minat menginap di hotel bintang lima dapat dijelaskan oleh nilai-nilai dari perceived luxury value. Berikut hasil dari koefisien determinasi berganda:

Tabel 5. Hasil dari Koefisien Determinasi Berganda

\begin{tabular}{ccc}
\hline $\mathbf{R}$ & $\mathbf{R}$ Square & Adjusted $\mathbf{R}$ Square \\
\hline $0,591^{\mathrm{a}}$ & 0,350 & 0,317 \\
\hline
\end{tabular}

Tabel 5 diatas menjelaskan bahwa nilai $\mathrm{R}=0,591$ yang berarti korelasi antara nilai utilitarian, nilai simbolik, nilai hedonis, nilai relasional, nilai finansial, dan minat menginap memiliki hubungan yang positif dan kuat karena nilai koefisien korelasi berada di antara $0,50 \leq R \leq 0,75$. Sementara, pengaruh variabel bebas terhadap variabel terikat ditunjukkan oleh angka adjusted $R$ square sebesar 0,317. Hal ini berarti 31,7\% minat menginap di hotel bintang lima dapat dijelaskan oleh persepsi konsumen terhadap luxury values yang terdiri dari variabel nilai utilitarian, nilai simbolik, nilai hedonis, nilai relasional, dan nilai finansial. Sementara sisanya sebesar $68,3 \%$ dipengaruhi oleh faktor-faktor lain yang tidak dianalisa dalam penelitian ini.

\section{Uji F}

Uji F digunakan untuk mengetahui signifikansi pengaruh variabel nilai utilitarian, nilai simbolik, nilai hedonis, nilai relasional, dan nilai finansial secara simultan terhadap minat menginap. Uji $\mathrm{F}$ dilakukan dengan membandingkan nilai antara $\mathrm{F}$ hitung dan $\mathrm{F}$ tabel.
Tabel 6. Hasil Uji F

\begin{tabular}{lccccc}
\multicolumn{6}{c}{ ANOVA $^{\mathrm{b}}$} \\
\hline Model & $\begin{array}{c}\text { Sum of } \\
\text { Squares }\end{array}$ & df & $\begin{array}{c}\text { Mean } \\
\text { Square }\end{array}$ & F & Sig. \\
\hline 1 Regression & 128.415 & 5 & 25.683 & 10.540 & $.000^{\mathrm{a}}$ \\
Residual & 238.806 & 98 & 2.437 & & \\
Total & 367.221 & 103 & & & \\
\hline
\end{tabular}

a. Predictors: (Constant), Nilai Finansial, Nilai Utilitarian, Nilai Simbolik, Nilai Hedonis, Nilai Relasional

b. Dependent Variable: Minat Menginap

Berdasarkan tabel 6 diatas, nilai $\mathrm{F}$ hitung sebesar 10,540 yang lebih besar dari 2,31 yang merupakan taraf nyata atau $\mathrm{F}$ tabel, dengan tingkat signifikansi sebesar 0,000 yang $<0,05$. Dari hasil pengujian di atas, diketahui bahwa Perceived Luxury Value (yang terdiri dari nilai utilitarian, nilai simbolik, nilai hedonis, nilai relasional dan nilai finansial) berpengaruh signifikan terhadap minat menginap di hotel bintang lima

\section{Uji t}

Uji t dilakukan untuk mengetahui seberapa besar pengaruh variabel bebas dari perceived luxury value secara parsial terhadap variabel terikat yaitu minat menginap. Hasil dari uji t dapat dilihat di Tabel 4 diatas. Jika dilihat dari tingkat signifikansi, maka dari hasil uji t dapat dilihat bahwa secara parsial nilai hedonis dengan nilai signifikansi 0,019 dan nilai finansial dengan signifiknasi 0,003 , berpengaruh signifikan terhadap minat menginap di hotel bintang lima karena memiliki signifikansi <0,05. Kemudian, untuk nilai utilitarian dengan nilai signifikansi 0,151 , nilai relasional dengan nilai signifikansi 0,960 dan nilai simbolik dengan tingkat signifikansi 0,979, memiliki pengaruh yang tidak signifikan karena $>0,05$. Dari hasil tersebut, maka dapat disimpulkan bahwa dari lima hipotesis yang diajukan, hanya hipotesis pertama saja yang ditolak dimana nilai utilitarian dari luxury values ternyata tidak berpengaruh signifikan terhadap minat menginap di hotel bintang lima. Sedangkan hipotesis kedua sampai kelima dinyatakan diterima.

\section{PEMBAHASAN}

Nilai hedonis dari luxury values merupakan nilai yang dipersepsikan paling tinggi diikuti oleh nilai utilitarian, finansial, relasional dan yang paling rendah adalah nilai simbolik. Nilai hedonis ini menjadi nilai yang paling diinginkan ketika menginap di hotel bintang lima karena konsumsi luxury biasanya bertujuan untuk memanjakan diri dan memberikan kepuasan emosi sehingga, konsumsi luxury identik dengan konsumsi hedonis konsumen. 
Perceived luxury value secara keseluruhan berpengaruh signifikan terhadap minat menginap di hotel bintang lima. Hasil ini mendukung penelitian sebelumnya yang dilakukan oleh Wu dan Yang (2018) yang mengemukakan bahwa perceived luxury value memiliki pengaruh yang signifikan terhadap minat menginap masyarakat Cina di hotel Luxury Cina. Nilai hedonis berpengaruh signifikan dan positif terhadap minat menginap di hotel bintang lima. Hasil ini mengkonfirmasi penelitian yang dilakukan Wu dan Yang (2018) dan Yang dan Mattila (2016) yang mengemukakan bahwa nilai hedonis memiliki pengaruh yang signifikan terhadap minat menginap di luxury hotel dan restoran. Hal ini dikarenakan industri perhotelan memiliki karakteristik yang berfokus pada penyediaan pengalaman dan kesenangan (Yang \& Mattila, 2016). Konsumen juga cenderung ingin memanjakan diri dan mendapat kesenangan saat menginap di hotel bintang lima (Wu \& Yang, 2018). Hotel bintang lima sendiri merupakan hotel dengan fasilitas yang lengkap, disertai dengan pelayanan yang penuh perhatian, maka konsumen dapat memperoleh rasa senang dan memanjakan diri melalui menginap di hotel bintang lima.

Nilai finansial berpengaruh signifikan dan positif terhadap minat menginap di hotel bintang lima. Hal ini juga sejalan dengan hasil penelitian Wu dan Yang (2018) serta Yang dan Mattila (2016) di industri hotel dan restoran luxury. Hasil ini juga mendukung analisis oleh Oxford Business Group yang berpendapat bahwa masyarakat Indonesia cenderung sensitif akan harga ("The luxury market", n.d.). Selain itu, mengingat mayoritas responden yaitu sebanyak $45,2 \%$, dalam penelitian ini adalah mahasiswa atau pelajar dengan uang saku atau pendapatan rata-rata per bulan di bawah Rp 5.000.000,00, maka nilai finansial akan sangat berpengaruh terhadap minat menginap. Hal ini dikarenakan pendapatan yang masih tergolong rendah menyebabkan responden untuk lebih sensitif akan pengeluaran dan manfaat yang didapatkan dari pengeluaran tersebut.

Nilai simbolik, nilai relasional, dan nilai utilitarian tidak berpengaruh signifikan terhadap minat menginap di hotel bintang lima. Hasil signifikansi untuk nilai utilitarian bertolak belakang dengan hasil penelitian Wu dan Yang (2018) dan Yang dan Mattila (2016) yang mengemukakan bahwa nilai utilitarian berpengaruh signifikan pada minat beli dalam industri perhotelan luxury. Hal ini dapat terjadi karena terdapat standar kualitas atau nilai utilitarian tinggi yang telah diasumsikan ada pada setiap produk dan jasa luxury. Dengan demikian masyarakat Indonesia juga cenderung berasumsi bahwa nilai utilitarian, dalam artian kualitas, fasilitas, dan layanan yang berkualitas, sudah pasti terdapat pada hotel bintang lima. Selain itu, jika melihat dari demografis responden dimana mayoritas responden melakukan travelling untuk berlibur, maka dapat dikatakan wajar jika nilai utilitarian tidak berpengaruh signifikan terhadap minat menginap. Hal ini dikarenakan saat berlibur, orang Indonesia pada umumnya akan banyak bepergian dan cenderung untuk tidak menghabiskan waktu di hotel untuk menikmati fasilitas dan pelayanan di hotel bintang lima.

Untuk nilai simbolik dikonfirmasi bahwa nilai ini memang tidak memiliki pengaruh yang signifikan terhadap minat menginap. Hal ini disebabkan oleh sifat responden yang umumnya lebih memilih untuk menunjukkan status dan kekayaan melalui produk tangible seperti tas, baju, dan lain-lain yang bermerek yang lebih jelas terlihat daripada melalui jasa seperti hotel bintang lima yang tidak terlihat/berwujud. Hotel juga merupakan industri yang menjual dan menyediakan pengalaman sehingga berfokus pada perasaan yang menyebabkan efek intangible atau tidak terlihat untuk konsumen atau tamu yang menikmati.

\section{KESIMPULAN DAN SARAN}

Dari hasil dan analisa yang telah dijelaskan diatas, maka dapat disimpulkan bahwa konsumen cenderung mempersepsikan luxury value melalui nilai hedonis, yang terindikasi dari menginap di hotel bintang lima sebagai cara untuk memanjakan diri dan memberikan banyak kesenangan. Setelah nilai hedonis, nilai utilitarian juga dipersepsikan sangat tinggi dimana hal ini terindikasi dari hotel bintang lima yang terpercaya dan layanan yang penuh perhatian yang mendorong responden untuk menginap. Bila dilihat dari masingmasing indikator, maka yang mendorong konsumen untuk menginap di hotel bintang lima adalah karena hotel bintang lima dapat dipercaya. Hal ini bisa saja dikarenakan responden menganggap hotel bintang lima yang terpercaya mampu menyediakan layanan dan fasilitas yang mampu memanjakan diri dan memberikan banyak kesenangan.

Perceived luxury value yang dilihat dari nilai hedonis dan finansial, berpengaruh signifikan terhadap minat masyarakat Indonesia untuk menginap di hotel bintang lima. Hal ini dapat disimpulkan bahwa kemampuan hotel bintang lima dalam memberikan kesenangan dan kenyamanan yang memanjakan para tamu yang menginap, serta membayar sesuai dengan manfaat yang didapatkan, semua ini mendorong minat konsumen untuk menginap di hotel bintang lima.

Sedangkan nilai utilitarian, simbolik, dan relasional, tidak berpengaruh signifikan terhadap minat masyarakat Indonesia untuk menginap di hotel bintang lima. Hal ini dapat disimpulkan bahwa fasilitas, pelayanan, hubungan dekat dengan hotel, serta menginap 
sebagai simbol kekuasaan dan status, tidak mendorong minat konsumen untuk menginap di hotel bintang lima.

Hasil dari penelitian ini diharapkan dapat memberikan masukan bagi hotel, khususnya bintang lima untuk dapat meningkatkan dimensi nilai hedonis dan nilai finansial melalui peningkatan kemampuan hotel bintang lima yang mampu menyenangkan dan memanjakan diri konsumen. Promosi atau iklan yang dibuat dapat menonjolkan fasilitas hotel yang memadai untuk memenuhi keinginan konsumen untuk berlibur, misalnya adanya shuttle bus untuk menuju lokasi wisata, dan cara penulisan harga yang terlihat sebanding dengan yang ditawarkan, sehingga dapat mempengaruhi psikologi konsumen dan meningkatkan minat beli. Cara lain yaitu dapat meningkatkan teknologi di dalam kamar seperti robot pembersih dan pengantar barang sebagai upaya meminimalisir kontak langsung antara karyawan hotel dengan konsumen dan memudahkan konsumen kapanpun ingin membersihkan kamar atau meminta suatu barang. Dengan peningkatan tersebut, diharapkan kemampuan yang ditawarkan hotel bintang lima kepada konsumen sesuai dengan harga tinggi yang dibayarkan (value for money).

Keterbatasan dalam penelitian ini adalah sebagian besar sampelnya adalah mahasiswa dengan rentang usia 17 hingga 22 tahun yang bisa saja tidak mewakili masyarakat kelas menengah ke atas yang umumnya merupakan demografi konsumen hotel bintang lima. Oleh karena itu diharapkan penelitian selanjutnya dapat mengambil sampel yang lebih bervariasi dengan usia yang lebih dewasa dan pendapatan yang lebih tinggi untuk dapat memberikan gambaran yang lebih jelas mengenai persepsi luxury value. Selain itu, dapat juga digunakan variabel-variabel lain yang tidak digunakan dalam penelitian ini untuk lebih memperjelas variabel-variabel yang mempengaruhi minat menginap. Kemudian, untuk memperdalam hasil yang didapatkan, diharapkan peneliti selanjutnya dapat menggali lebih dalam tentang nilai yang dipersepsikan oleh konsumen luxury melalui penelitian kualitatif.

\section{DAFTAR PUSTAKA}

Alan, A.K., Dursun, I., Kabadayi, E.T., Aydin, K. \& Anlagan, F. (2016). What influence the repurchase intention for luxury brands?- the relative impacts of luxury value. International Business Research, 9(5), 11-24.

Amelia, R. \& Hidayatullah, S. (2020, April). The effect of instagram engagement to purchase intention and consumers' luxury value perception as the mediator in the skylounge restaurant. International Journal of Innovative Science and Research Technology, 5(4), 958-966.
Amin, S. \& Tarun, M. T. (April, 2019). Enhancing green hotel visit intention: role of green perceived value, perceived consumer effectiveness and environmental knowledge. International Business Research, 12(5), 123-132.

Armstrong, G., Adam, S., Denize, S., Kotler, P. (2015). Principles of marketing. ( $6^{\text {th }}$ ed.). Australia: Pearson.

Barrows, C.W., Powers, T., \& Reynolds, D. (2011). Introduction to management in the hospitality industry. (10th ed.). New Jersey: John Wiley \& Sons, Inc.

Chen, A., \& Peng, N. (2014). Examining chinese consumers' luxury hotel staying behavior. International Journal of Hospitality Management, 39(2014), 53-56.

Chen, A., \& Peng, N. (2018). Examining consumers' intentions to dine at luxury restaurants while traveling. International Journal of Hospitality Management, 71(2018), 59-67.

Fernández, R.S. \& Bonillo, M.A.I. (2007. Desember). The concept of perceived value: a systematic review of the research. Marketing Theory, 7(4), 427-451.

Flint, D.J., Woodruff, R.B., \& Gardial, S.F. (1997). Customer value change in industrial marketing relationships: A call for new strategies and research. Industrial Marketing Management, 26(1997), 163-175.

Freitag, J. (2019, November 19). Data shows resilience for luxury hotels globally. Hotel News Now. Retrieved from https://www.hotelnewsnow. com/Articles/299107/Data-shows-resilience-forluxury-hotels-globally.

Graf, A. \& Maas P. (2008, April). Customer value from a customer perspective: a comprehensive review. Journal für Betriebswirtschaft, 58(1), 120.

Industri hotel mulai menggeliat. (2020, September 7). Jawa Pos, p. 15.

Junaidi, N.W. (2015). Analisa Pengaruh Customer Value terhadap Repurchase Intention dengan Customer Satisfaction sebagai Variabel Intervening di Pisa Kafe Manyar Surabaya (Undergraduate Thesis, Universitas Kristen Petra, 2015). Retrieved from http://publication.petra.ac.id/ index.php/manajemen-pemasaran/article/view/ 3342/3023.

Kang, J (2018). Finding desirable post-consumption behaviors-an investigation of luxury value \& romantic brand love relationship. International Journal of Contemporary Hospitality Management, 30(9), 2984-3003.

Lien, C., Wen, M., Huang, L., \& Wu, K. (2015). Online hotel booking: The effects of brand image, price, trust, and value on purchase intention. Asia Pacific Management Review, 20(4), 210-218. 
Liu, M.T., Wong, I.A., Tseng, T., Chang, A.W., \& Phau, I. (2017). Applying consumer-based brand equity in luxury hotel branding. Journal of Business Research, 81(2017), 192-202.

Peng, N., \& Chen, A. (2019). Examining consumers' luxury hotel stay repurchase intentions-incorporating a luxury hotel brand attachment variable into a luxury consumption value model. International Journal of Contemporary Hospitality Management, 31(3), 1348-1366.

Raza, M. A., iddique, A. N., Awan, H.M. \& Bukhari, K. (2012, December). Relationship between service quality, perceived value, satisfaction, and revisit, intention hotel intention. Interdisciplinary Journal of Contemporary Research in Business, 4(8), 788-805.

Salanto, F. (2018, June 20). Bali's hotel industry looks set to gain strength in 2018. Gapura Bali. Retrieved from https://www.gapurabali.com/ news/2018/06/20/balis-hotel-industry-looks-setgain-strength-2018/ 1529464513.

Sari, D., \& Kusuma, B. (2014, June). Does luxury brand perception matter in purchase intention? A comparison between a Japanese brand and a German brand. ASEAN Marketing Journal, 6(1), 50-63.

Shukla, P. \& Purani, K. (2012). Comparing the importance of luxury value perceptions in crossnational contexts. Journal of Business Research, 65(2012), 1417-1424.

Suarna, N. (2020, August 3). Okupansi villa mulai naik, didominasi wisatawan lokal dan domestik. Bali Express Jawa Pos. Retrieved from https:// baliexpress.jawapos.com/read/2020/08/03/2073 44/okupansi-villa-mulai-naik-didominasiwisatawan-lokal-dan-domestik.
The luxury market: The ups and downs of growing demand for high-end retail. (n.d.). Oxford Business Group. Retrieved from https://oxford businessgroup.com/analysis/luxury-market-ups-anddowns-growing- demand-high-end-retail.

Tynan, C, McKechnie, S, \& Chhuon, C. (2010). Cocreating value for luxury brands. Journal of Business Research, 63(2010), 1156-1163.

Woodruff, R.B. (1997). Customer value: The next source for competitive advantage. Journal of the Academy of Marketing Science, 25(139), 139153.

Wu, B. \& Yang, W. (2018). What do Chinese Consumers want? A value framework for Luxury hotels in China. International Journal of Contemporary Hospitality Management, 30(4), 20372055.

Yacob, S., Johannes, \& Qommariah M. (2019). Visiting intention: a perspective of destination attractiveness and image in Indonesia rural tourism. Sriwijaya International Journal of Dynamic Economics and Business, 3(2), 122133.

Yang, F., \& Lau, V.M.C. (2015). "LuXurY" hotel loyalty - a comparison of Chinese Gen X \& Y tourists to Macau. International Journal of Contemporary Hospitality Management, 27(7), 1685-1703.

Yang, W. \& Mattila, A. S. (2016). Why do we buy luxury experiences? Measuring value perceptions of luxury hospitality services. International Journal of Contemporary Hospitality Management, 28(9), 1848-1867.

Yulisetiarini, D., Subagio, A., Paramu, H., \& Irawan, B. (2017). Customer repurchase intention and satisfaction in online shopping. International Business Management, 11(1), 215-221. 